М.А. Цомая

\title{
ЭВОЛЮЦИЯ ЕВРАЗЭС:
} ПОЛИТИЧЕСКИЕ АМБИЦИИ ИЛИ ОБЬЕКТИВНАЯ РЕАЛЬНОСТЬ

\begin{abstract}
Аннотация: В статье рассматриваются особенности современного этапа отнотений стран-участниц ЕврАзЭС, механизмы перехода к следующей стадии экономического союза - ЕЭП и его отличительные черты. Создание наднациональных органов ставится во главу угла при продвижении к конечному этапу экономического взаимодействия стран. Исследуются причины углубления сотрудничества странучастнии ЕврАзЭС за последние два года, выносятся предположения относительно основных движущих сил, приведших к углублению интегращии внутри ЕврАзЭС.
\end{abstract}

Ключевые слова: Политология, ЕврАзЭС, Таможенный союз, Россия, ЕЭП, Надначиональный орган, Сотрудничество, ВТО, ОДКБ, ШОС

$\Phi$ ункционирование ЕврАзЭС в последние два года демонстрирует признаки устойчивого стремления к дальнейшему углублению интеграции внутри союза. При этом следует отметить некоторые специфические черты сотрудничества странучастниц ЕврАзЭС:

1. Наблюдается постепенная конкретизация конечной модели союза, а также структуры руководящих органов будущего экономического объединения.

2. Формализация модели союза позволила подобрать соответствующую правовую модель: первоначальная организационно-правовая форма союза Таможенный союз, активно используется многими государствами и не противоречит международному праву, нормы которого обеспечивают процесс создания и функционирования ТС. Создание ТС и участие того или иного государства в нем не нарушает международный правопорядок, не меняет кардинальным образом имеющиеся международные связи с третьими странами ${ }^{1}$.

3. Факт обладания ЕЭП признаками наднационального характера свидетельствует об эволюционировании экономического союза ЕврАзЭС.

Стоит отметить, что создание наднационального органа ТС не является ущемлением или ограничением суверенитета государства-участника: может измениться объем полномочий органов государственной власти, но суверенитет как качественная категория и

${ }^{1}$ Комендантов С.В. Международно-правовые последствия создания Таможенного союза в рамках ЕврАзЭС.// Российский внешнеэкономический вестник. 2010. №1. С. 37-42. признак государства как первичного субъекта международного права остается. Право вступать в международные соглашения является атрибутом суверенитета государства ${ }^{2}$.

4. Для эффективного обслуживания интересов интеграции созрела необходимость сделать акцент на дополненность законодательного права ЕЭП в национальное законодательство стран-участниц. Для реализации этого, предполагается основать в ЕЭП специальный экономический режим на принципах свободы торговли товарами, услугами, а также свободы передвижения финансового и человеческого капитала.

В конечном счете, учитывающая национальные интересы экономическая политика ЕЭП, позволит обеспечить благоприятное функционирование государств внутри союза, а ориентация на внешние доминанты поможет занять достойное положение союза на мировом рынке и достичь следующего этапа в развитии отношений стран-участниц - создания евразийского экономического союза.

Механизм достижения конечных целей функционирования ЕЭП изложен в Концепции формирования ЕЭП ${ }^{3}$.

Согласно ей, для реализации принципа свободного движения товаров необходимо устранение изъятий из режима свободной торговли и снятие ограничений во взаимной торговле на основе унификации таможен-

2 Лукашук И.И. Международное право. Общая часть. М., 2005

${ }^{3}$ http://archive.kremlin.ru/text/docs/2003/09/52480.shtml (дата обращения: 02.11.2012) 
DOI: $10.7256 / 1812-8696.2013 .04 .15$

Международная политика

ных тарифов, формирование общего таможенного тарифа, установленного на основе согласованной государствами-участниками методики, мер нетарифного регулирования, применение инструментов регулирования торговли товарами с третьими странами. Механизмы применения во взаимной торговле антидемпинговых, компенсационных, специальных и защитных мер будут преобразовываться в единые правила в области конкуренции и возможных мер государственной поддержки, с учетом аспектов мировой торговли.

В целях дальнейшего вступления стран-участниц ЕЭП в ВТО подписан Договор о порядке функционирования Таможенного союза в рамках многосторонней торговой системы, закрепивший основные принципы присоединения государств-членов Таможенного союза.

С целью обеспечения свободы движения товаров, услуг, труда и капитала предполагается предоставление национального режима предприятиям-резидентам Сторон в оказании услуг, унификация требований к ним, взаимное признание лицензий в лицензируемых видах деятельности ${ }^{4}$.

При формировании общего рынка труда в ЕЭП будет реализовано свободное передвижение рабочей силы внутри союза, урегулирован правовой статус граждан одного государства, постоянно проживающих на территории другого государства-участника ЕЭП, обеспечен свободный доступ к получению образования, единообразное применение правил и требований к трудовым ресурсам и режиму доступа на рынок труда 5 . Для этого необходимо создание специального наднационального органа в ЕЭП по решению миграционных вопросов.

Основные задачи, связанные с совершенствованием межгосударственного миграционного законодательства, определяются необходимостью унификации базовых понятий в области миграции, введением упрощенного порядка заключения трудового договора с трудящимся-мигрантом, разработкой стратегии развития межгосударственного миграционного законодательства и единой концепции государственной миграционной политики.

\footnotetext{
${ }^{4}$ Мансуров Т.А. . Таможенный союз - решающий этап евразийской интеграции.// Евразийская интеграция: экономика, право, политика. 2010. № 7. С.37-43.

5 http://ru.wikipedia.org/wiki/\%C5\%E4\%E8\%ED\%EE\%E5 \% FD $\%$ EA $\%$ EE $\%$ ED $\%$ EE $\%$ EC $\%$ E $8 \%$ F $\%$ E5\%F1\%EA $\%$ EE $\%$ E5_\%EF\%F0\%EE\%F1\%F2\%F0\%E0\%ED $\%$ F $1 \%$ F $2 \%$ E2 $\%$ EE (дата обращения: 02.11.2012)
}

При создании общего рынка капитала будет обеспечен взаимный доступ на рынок финансовых, банковских, страховых услуг, создана единая платежно-расчетная система, а также будут приведены в соответствие нормы валютного регулирования для формирования в конечном счете общего валютного рынка.

Для углубления финансовой интеграции предполагается:

1) помощь более развитых стран объединения (России и Казахстана) в формировании финансовых рынков менее развитых стран;

2) осуществление совместных инвестиций, для чего в ЕЭП учрежден многосторонний банк развития Евразийского банка развития (ЕАБР);

3) координация параметров основных макроэкономических показателей для повышения устойчивости экономического развития;

4) углубление сотрудничества в валютной сфере - реализация мероприятий по расширению использования национальных валют в обеспечении внешней торговли, согласование принципов и правил установления обменных курсов национальных валют странучастников ЕЭП, сближение подходов по формированию и проведению валютной политики, формирования интегрированного валютного рынка, совершенствования механизма платежно-расчетных отношений между странами.

Для обеспечения свободного рынка услуг и инвестиций, кроме унификации законодательства в сфере услуг и инвестиций, взаимного признания лицензий, предполагается создание и функционирование наднационального органа по регулированию финансового рынка государств-участников ЕЭП.

Следует отметить, что эволюция ЕврАзЭС не является следствием лишь одних политических факторов, но и определяется назревшей экономической потребностью к объединению с лидером экономической группы - Российской Федерацией. Доминирующее положение России обусловлено не только военным потенциалом и политическим первенством страны, но и наиболее развитой экономикой. Именно Россия является доминантой как во внешней торговле всего союза, так и во взаимной торговле внутри ЕврАзЭС. Причем, сильная доминанта партнера с достаточно высоким уровнем экономики может позволить создать устойчивое экономическое объединение со странами, даже находящимися на более низком уровне экономического развития, ввиду так называемого эффекта 


\section{Политика и общество 4 (100) • 2013}

масштаба, т.е. когда негативное влияние слабого союзника, обусловленное низким уровнем его экономического развития, нивелируется относительным превосходством сильного союзника, показывающим, в том числе, и высокие валовые показатели.

Так, например, слабая обеспеченность Беларуси собственными энергетическими ресурсами (обеспеченность собственными ресурсами составляет около 10\%, преимущественно включающая в себя нефть, торф, бурый уголь и горючий сланец $\left.{ }^{6}\right)$, с одной стороны, и «двойная игра» с Западом, с другой стороны, привели к тому, что страна до сих пор находится на стадии переходного периода, а Россия, не может в полной мере пользоваться этим важным транспортным коридором, связывающим ее с дальним зарубежьем. Пока Беларуси, по-видимому, не удалось создать надежную несущую конструкцию своего участия в международном разделении труда, не зависящую от тесного взаимодействия с Россией, а точнее, от опоры на энергетические поставки и российский рынок» ${ }^{7}$, объективная реальность заставляет Беларусь сделать выбор в пользу углубления сотрудничества с Россией в рамках ЕврАзЭС, что, возможно, сулит ей большие экономические выгоды, нежели при усилении западного вектора.

Работа России по усилению своего политического влияния на мировой арене велась одновременно, как в западном векторе (выстраивание отношений с Беларусью), доказательством чему является создание СГРБ, так и в южном направлении, что фактически привело к созданию ЕврАзЭС.

Стратегическая значимость для России стран Центральной Азии, как и с Беларусью, связана с их ролью транспортного моста, но уже в другом направлении: скажем, поток углеводородов по ним может идти и в западном (в сторону Евросоюза), и в южном (к побережью Индийского океана), и в восточном (к Китаю, Японии и Тихому океану) направлениях. Кроме того, становится важной и железнодорожная сеть этого региона.

Следует также отметить необходимость установления лидерства в этом регионе для России: территориальные споры внутри стран, межнациональные

${ }^{6}$ ЕврАзЭС сегодня - 2011. URL: http://www.evrazes.com/ about/evrazestoday (дата обращения: 02.11.2012).

${ }^{7}$ Боришполеи К.П., Чернявский С.И. Российско-белорусские отношения: вместе или рядом.// ЕЭИ. 2012. № 2 (15) . C. 68-74. конфликты, обострение взаимоотношений Узбекистана с Таджикистаном и Киргизией ввиду ограниченности водных ресурсов, неустойчивость границ с нестабильным Афганистаном, в котором в последнее время усилилась деятельность террористических и экстремистских организаций, грозят дестабилизацией политической и военной ситуации в регионе ${ }^{8}$.

Страны Центральной Азии видят Россию в качестве основного партнера не только из-за возможности пользоваться ее авторитетом для защиты своего суверенитета, но и ввиду тесного торгово-экономического сотрудничества: Узбекистан, Кыргызстан, Таджикистан и Туркмения ввозили из России 100 \% проката черных металлов и леса, бумаги, автомобильных шин, удобрений, резины, пластмасс, на Россию пока сориентирована и региональная транспортная система 9 .

Из всех стран центрально-азиатского региона Казахстан - наиболее влиятельный, стабильный и предсказуемый партнер России, на сегодня ставший ключевым геостратегическим партнером для России. Первоочередными задачами для России при сотрудничестве с Казахстаном в военной области военного является сохранение доступа к крупным военно-стратегическим объектам бывшего СССР с целью эксплуатации для обеспечения обороноспособности России. Как заметил один из исследователей центрально-азиатских проблем, «идеологически на российско-казахстанской «оси» держится все центрально-азиатское пространство СНГ ${ }^{10}$.

Для Киргизии развитие отношений с Россией также остается главным вектором внешней политики, что объясняется в первую очередь слабостью страны и необходимостью существенной политической поддержки; не последнюю роль в сотрудничестве с Россией играет острая нехватка денежных средств с целью реализации важных стратегических для страны проектов. Внутреннюю ситуацию в республике нельзя назвать стабильной - страна неофициально делится на северные и южные кланы, между которыми довольно не-

\footnotetext{
${ }^{8}$ Бирюков С. Россия - Центральная Азия: стратегический провал или тактическая пауза. URL: http://www.apn.ru/ publications/article1333.htm (дата обращения: 02.11.2012).

9 Ачкасова В.А., Гаевский Э.В. Структура политических интересов России в Центральной Азии.// Евразийская интеграция: экономика, право, политика. 2012. № 11. С. 123-129.

${ }^{10}$ Лузянин С. Центральная Азия - измерения безопасности и сотрудничества. URL: http://www.perspektivy.info/rus/desk/ centralnaja_azija_izmerenija_bezopasnosti_i_sotrudnichestva _2012-02-06.htm (дата обращения: 02.11.2012).
} 
приязненные отношения; обстановку также обостряет и присутствие узбеков, что вызывает напряжённость между общинами.

Для России важность сотрудничества с этой центрально-азиатской республикой связана, как с военно-стратегической сферой, так как эта страна является союзником России по ОДКБ, ШОС, ЕврАзЭс, так и с энергетической сферой (интерес России связан со строительством новых ГЭС и водохранилищ).

Таджикистан, также ввиду своей «экономической слабости и хрупкого коалиционного равновесия кланов (бывших «кулябцев» и «исламистов»), объективно нуждается в политическом и экономическом посредничестве и участии России» ${ }^{11}$. Кроме того, сложные отношения Таджикистана с Узбекистаном также делают выгодными его партнерство с внешней влиятельной силой, в роли которой выступает Россия.

Интерес для России во взаимодействии с Таджикистаном связан в возможности использования ранее принадлежавших СССР военных объектов, а также в углублении сотрудничества в энергетической сфере.

Таким образом, следует отметить, что при взаимодействии стран в составе ЕврАзЭС выделяются шесть стратегических направлений, объективно позволяющих, в дополнение к политическому желанию лидеров стран-участниц ЕврАзЭС, продвинуться к конечной цели - созданию евразийского экономического союза:

- развитие совместных энергетических проектов приобретают особую значимость ввиду высокой востребованности электроэнергии, включая стратегические направления на Индию, Китай, Европу (особенно Германию, ввиду отказа (на сегодняшний день) от выработки на своей территории атомной энергии). Кроме того, многие из стран союза обладают большим энергетическим потенциалом (Таджикистан, Кыргызстан), но не имеют возможности за счет собственных средств их реализовать. Важность сотрудничества стран в этой отрасли состоит еще и в том, что при реализации энергии необходима разветвленная сеть, для строительства которой необходимо взаимодействие с соседями.

- оптимизация транзитных издержек при тесном сотрудничестве стран ЕврАзЭС позволит многим странам, и не только странам союза, существенно со-

${ }^{11}$ Гусев Л. Россия - страны Центральной Азии: перспективы развития отношений и сотрудничества. URL: http://www.ru.dev.jneo.wiw.ru/node/13475 (дата обращения: 02.11.2012). кратить расходы при транспортировке груза в другую страну. Участники ЕврАзЭС (Казахстан, Таджикистан) уже сейчас ведут активное дорожное строительство, понимая всю важность развития транспортных коридоров.

- сотрудничество в области сельского хозяйства чрезвычайно важно для всех стран СНГ, и, в первую очередь, стран Центральной Азии, для обеспечения продовольственной безопасности стран.

- тесное сотрудничество стран в составе ЕЭП позволит открыть новые возможности по внедрению современных технологий. «Благоприятные торгово-экономические отношения и кооперация с Россией позволят существенно интенсифицировать взаимоотношения в области развития машиностроительных производств».

- осуществление совместных договоренностей по легитимности миграции позволит не только существенно снизить поток нелегальных мигрантов, но и выстроить дополнительное препятствие для незаконного оборота наркотиков. Особенно это становится актуальным для Кыргызстана и Таджикистана, граничащих с Афганистаном.

- сотрудничество в финансовой сфере, так как совместные усилия позволят внедрить новые технологии и выйти банковской сфере стран ЕврАзЭС на новый этап развития, стать более прозрачной для зарубежных партнеров, что сделает ЕврАзЭС более привлекательной для инвестиций.

\section{Библиография:}

1. Комендантов С.В. Международно-правовые последствия создания Таможенного союза в рамках ЕврАзЭС.// Российский внешнеэкономический вестник. 2010. №1. С. 37-42.

2. Лукашук И.И. Международное право. Общая часть. М., 2005.

3. Мансуров Т.А. . Таможенный союз - решающий этап евразийской интеграции.// Евразийская интеграция: экономика, право, политика. 2010. № 7. C.37-43.

4. ЕврАзЭС сегодня - 2011. URL: http://www. evrazes.com/about/evrazestoday (дата обращения: 02.11.2012).

5. Боришполец К.П., Чернявский С.И. Российскобелорусские отношения: вместе или рядом.// ЕЭИ. 2012. № 2 (15) . С. 68-74. 


\section{Политика и общество 4 (100) • 2013}

6. Бирюков С. Россия - Центральная Азия: стратегический провал или тактическая пауза. URL: http://www.apn.ru/publications/article1333.htm (дата обращения: 02.11.2012).

7. Ачкасова В.А., Гаевский Э.В. Структура политических интересов России в Центральной Азии.// Евразийская интеграция: экономика, право, политика. 2012. № 11. С. 123-129.

8. Лузянин С. Центральная Азия - измерения безопасности и сотрудничества. URL:

http://www.perspektivy.info/rus/desk/centralnaja azija_ izmerenija_bezopasnosti_i_sotrudnichestva_ 2012-02-06.htm (дата обращения: 02.11.2012).

9. Гусев Л. Россия - страны Центральной Азии: перспективы развития отношений и сотрудничества. URL: $\quad$ http://www.ru.dev.jneo.wiw.ru/node/13475 (дата обращения: 02.11.2012).

\section{References (transliteration):}

1. Komendantov S.V. Mezhdunarodno-pravovye posledstviya sozdaniya Tamozhennogo soyuza v ramkakh EvrAzES.// Rossiyskiy vneshneekonomicheskiy vestnik. 2010. №1. S. 37-42.
2. Lukashuk I.I. Mezhdunarodnoe pravo. Obshchaya chast'. M., 2005.

3. Mansurov T.A. . Tamozhennyy soyuz - reshayushchiy etap evraziyskoy integratsii.// Evraziyskaya integratsiya: ekonomika, pravo, politika. 2010. № 7. S.37-43.

4. Borishpolets K.P., Chernyavskiy S.I. Rossiysko-belorusskie otnosheniya: vmeste ili ryadom.// EEI. 2012. № 2 (15) . S. 68-74.

5. Biryukov S. Rossiya — Tsentral'naya Aziya: strategicheskiy proval ili takticheskaya pauza. URL: http:// www.apn.ru/publications/article1333.htm (data obrashcheniya: 02.11.2012).

6. Achkasova V.A., Gaevskiy E.V. Struktura politicheskikh interesov Rossii v Tsentral'noy Azii.// Evraziyskaya integratsiya: ekonomika, pravo, politika. 2012. № 11. S. 123-129.

7. Luzyanin S. Tsentral'naya Aziya - izmereniya bezopasnosti i sotrudnichestva. URL: http://www.perspektivy.info/rus/desk/centralnaja_azija_izmerenija_bezopasnosti_i_sotrudnichestva_2012-02-06.htm (data obrashcheniya: 02.11.2012).

8. Gusev L. Rossiya - strany Tsentral'noy Azii: perspektivy razvitiya otnosheniy i sotrudnichestva. URL: http:/www.ru.dev.jneo.wiw.ru/node/13475 (data obrashcheniya: 02.11.2012). 